\title{
Q1 Evaluations of the quality of "pata-de-vaca" (Bauhinia forficata Link) sold in Brazil
}

Joyce Cabral Rodrigues ${ }^{1}$

Elaine Santiago Brilhante de Albuquerque ${ }^{2}$

Ana Cláudia de Macêdo Vieira ${ }^{3}$

\begin{abstract}
The genus Bauhinia L. (Leguminosae), popularly known as "pata-de-vaca", presents wide diversity in Brazil and comprises both native and exotic species. The species is most widely known in popular medicine is the Bauhinia forficata Link, it's also called "true pata-de-vaca", and it consists of a small tree whose leaves are used in the form of infusions to treat diabetes. Since the genus Bauhinia has characteristic bilobed leaves, traditional phytotherapeutic products that should be composed of $B$. forficata leaves are often falsified by replacing them with other species of the genus. We acquired samples of 10 different commercial packages of "pata-de-vaca" being sold as herbal drugs in various regions of Brazil and analyzed them in terms of their macro and microscopic composition. For comparison, we conducted a morpho-anatomical study of the leaves from the standard species and analyzed the scientific literature. The packages themselves and the labels were evaluated based on ANVISA health authority standards. Almost all leaf samples had anatomical characters different from the standard leaf, indicating they were not authentic. In addition, all of the packages contained contaminants. Thus, all samples were rejected based on the criteria above. These types of products, in addition to misinformed consumers, can present considerable risks to their health.
\end{abstract}

Keywords: Fabaceae. Herbal drugs. Medicinal plants. Medicinal tea. Quality control. Traditional herbal medicinal product.

\section{Introduction}

There has been a trend on healthier life habits among Brazilians, increasing interest for "natural therapies" and the use of traditional medicinal plants (SILVEIRA; BANDEIRA; ARRAIS, 2008). However, the dissemination of the use of medicinal plants, especially for self-medication, is mainly driven by economic considerations and their easy access by large segments of the population (SOUZA-MOREIRA; SALGADO; PIETRO, 2010). The World Health Organization (WHO, 2002) has consequently become aware of the negligence surrounding possible toxicity of plant remedies, especially when compared to conventional modern therapies. The erroneous identification of plants and the nonconventional use of traditional medicines present potential risks and can result in ineffective therapies and adverse reactions (WHO, 2002). Capasso et al. (2000) pointed out natural products, such as plant-derived drugs, and phytotherapeutics can reduce the efficiency of conventional treatments

1 Universidade Federal do Rio de Janeiro (UFRJ), Faculdade de Farmácia, Laboratório de Farmacobotânica. joycecr.ufrj@gmail.com. Av. Carlos Chagas Filho, 373, Bloco A2, Sala 22, Ilha do Fundão, Rio de Janeiro (RJ), 21941-902.

2 UFRJ - Faculdade de Farmácia, Laboratório de Farmacobotânica. elaine.ufrj@hotmail.com.

3 UFRJ - Faculdade de Farmácia, Laboratório de Farmacobotânica. anavieira@gmail.com. 
or even magnify their effects. Likewise, there is no effective guarantee the herbal drugs available commercially are efficient, safe or of true quality. In light of the popular and institutional interest in phytotherapeutic plants, Brazilian Health Ministry has introduced National Policies of Integrative and Complementary Practices to Unified Health System (SUS) designed to amplify the therapeutic options offered to users of that health system, with guarantees of access to medicinal plants, phytotherapeutics and other related services with safety, efficiency, and quality (BRASIL, 2006). One of the instruments used to strengthen that policy is the National List of Medicinal Plants of Interest to the SUS (RENISUS), which currently comprises 71 plant species with pharmacological potential (BRASIL, 2015).

The medicinal potential of Bauhinia L. is quite high, as three representatives of that genus are included in the RENISUS list: B. affinis, B. forficata, and B. variegata. Additionally, ethnobotanical studies undertaken by Pantoja and Lopes (2012) demonstrated that $B$. forficata was among the 10 medicinal plant species most cited by traditional users. According to Vaz and Tozzi (2005), the genus Bauhinia belongs to the family Leguminosae and comprises approximately 300 species; approximately $70 \%$ of which can be found in Brazil. Their leaves are deeply divided in the middle, forming two distinct lobes that resemble the hooves of cattle, so they are popularly known as pata-de-vaca and unha-de-boi (DI STASI; HIRUMA-LIMA, 2002; VAZ; TOZZI, 2005; LORENZI; MATOS, 2008). According to Silva e Cechinel-Filho (2002), the leaves, stems and roots of Bauhinia species are often consumed by Brazilians in the form of teas or other phytotherapeutic preparations to treat a number of infirmities. Among these species, Bauhinia forficata Link is most well-known within the scientific world due to its growing use in popular medicine as an anti-diabetic medicine; therefore, it is often referred to as the "true pata-de-vaca" (DI STASI et al., 2002; SILVA; CECHINEL-FILHO, 2002; SILVA et al., 2002; LINO et al., 2004; VENDRUSCOLO; MENTZ, 2006; MENEZES et al., 2007; BOSCOLO; VALLE, 2008; CUNHA-LIMA et al. , 2008; CAZAROLLI et al.,2009; DEFANI et al., 2011; TROJAN-RODRIGUES et al., 2012; BALBINOT; VELASQUEZ; DÜSMAN, 2013).

Bauhinia forficata is native to Brazil and grows in the Atlantic Forest in humid sites (rarely within the forest itself) and often on slopes and in secondary formations. According to Lorenzi and Matos (2008), B. forficata is a spiny, semi-deciduous tree with an open canopy, from 5-9 m tall, with a light colored trunk. It has bilobed leaves and resembles the hoof of a cow. The flowers are white, arranged in axillary racemes, and the fruits are flattened, deciduous pods. According to Di Stasi and Hiruma-Lima (2002), the species has ornamental value due to its showy flowers, although other species of the same genus such as $B$. blakeana and $B$. variegata are preferred because $B$. forficata is covered with thorns. These exotic species have been widely used in remedies because of their immediately availability and physical resemblance to $B$. forficata. However, they have not been tested in terms of their medicinal efficiency and safety (LORENZI; MATOS, 2008).

Phytochemical analyses of extracts of plants from the genus Bauhinia have identified their main components as steroidal glycosides, triterpenes and lactons, with an abundance of free flavonoids and glycosides (SILVA; CECHINEL-FILHO, 2002; MARQUES et al., 2012; PEIXOTO-SOBRINHO et al., 2012). Only B. forficata, however, demonstrates the presence of the flavonoid kaempferitrina in its leaves (a compound known for its hypoglycemic activity), which is used as an analytical marker to identify extracts and preparations made from that species (SALATINO et al., 1999; HAVSTEEN, 2002; SILVA; CECHINEL-FILHO, 2002; SOUSA et al., 2004; CAZAROLLI et al., 2006).

In light of these studies, the use of $B$. forficata as a medicinal plant to treat Diabetes mellitus appears justified. While its mechanism of action is not totally clear, none of the above cited studies demonstrated any potential toxic effects - although ANVISA has not confirmed its complete safety, as 
reported by Balbino and Dias (2010). There is a number of publications that have indicated negative results in terms of the anti-hypoglycemia activity of $B$. forficata, including a paper by Russo et al. (1990).

The macroscopic similarities on leaves from different Bauhinia species have resulted in the adulteration of herbal drugs and herbal inputs by substituting (or adding) the leaves of other species from that genus since, once they are triturated, they cannot be easily distinguished from $B$. forficata. These aspects make quality control of this plant extremely relevant, and microscopic evaluations can be used to identify the substitution of $B$. forficata by other species of the same genus.

As such, we evaluated the quality of herbal drugs sold as "pata-de-vaca" in Brazil through macro and microscopic examinations of the leaf material, comparing it with the morpho-anatomical study of the leaves from Bauhinia forficata Link and with the scientific literature in addition to evaluating the packaging and labeling of the herbal drugs for compliance with government standards.

\section{Material and methods}

\section{Analyses of packaging and labeling}

We acquired 10 packages of pata-de-vaca from 10 different manufacturers of herbal drugs, sold in shops in the states of Bahia (1), Espírito Santo (1), Goiás (1), Minas Gerais (1), Pará (1) and Rio de Janeiro (5), in Brazil. All of the samples were acquired and evaluated within the period from October/2012 to March/2014. We evaluated the packaging and labeling of the samples based on government criteria -RDC no 10/10 (BRASIL, 2010) applicable during the studied period. Although the newest regulations -RDC no 26/14 (BRASIL, 2014) concerning the registry of herbal medicines and the regulation of traditional herbal medicine products are similar to the older regulations, they contain more details concerning the necessities of primary and secondary packaging.

The integrity and opacity of the packages were analyzed according to the criteria of RDC 10/10 (BRASIL, 2010). The weights of the contents were compared to the weights printed on the labels by their manufacturers and were analyzed according to the published norms of INMETRO (BRASIL, 2008) that specify allowed weight variations of less than $9 \%$ for samples with nominal contents up to $50 \mathrm{~g}$.

\section{Botanical evaluations}

The purchased samples were evaluated in terms of their microscopic aspects and appearances.

For these evaluations, the contents of the samples were poured into white trays and analyzed in detailed visual examinations that compared them with the morphological patterns of $B$. forficata as described by Miyake; Akisue; Akisue (1986), Lorenzi and Matos (2008), and Lusa and Bona (2009). The commercial samples were divided into four parts (ANVISA, 2010), one of which was rehydrated in a $50 \%$ ethanol: glycerin solution (2:1).

For the microscopic analyses, the hydrated sample portions were sectioned by hand, stained following the methodology of Bukatsch (1972), and subsequently mounted on semi-permanent slides for observation by light microscopy. To examine the adaxial and abaxial faces of the leaf epidermis, small rectangular regions were excised from the intercostal region of the middle third of the leaf blade and subsequently warmed in a 1:1 ( $/ \mathrm{v}$ ) solution of $20 \%$ hydrogen peroxide and glacial acetic acid (FRANKLIN, 1945). The epidermal sections were then stained with hydro-alcohol Safranin (STRASBURGER, 1924), mounted in 50\% glycerin. 
The sections were also examined under polarized light in order to analyze birefringent cell constituents such as prismatic crystals and druses. The solubility of these constituents was tested by immersing the leaf sections in $2 \%$ hydrochloric acid solution for 30 minutes (HOWARTH; WARNE, 1959).

The authenticity of the commercial samples was verified through comparison with morphoanatomical studies of the $B$. forficata leaf conducted by Miyake, Akisue and Akisue (1986), Donato (1995), Lusa and Bona (2009). Additionally, verified samples of this species were collected in the Guapimirim Municipal Park in the state of Rio de Janeiro, Brazil. The species identification was verified by Dr. Angela Studart F. Vaz of the Instituto de Pesquisa do Jardim Botânico do Rio de Janeiro, and voucher material was deposited in the herbarium of the Instituto de Biologia of Universidade Federal do Rio de Janeiro (RFA) under record number 40753. Histological sections were made from its leaves (midvein and lateral primary veins and petiole) and were used as standards following the same techniques above. However, the anatomical description of the proximal and distal pulvini of the standard leaves is not included here as there were so few of these structures present in the commercial samples, with those available so badly conserved that it made any comparative analysis difficult.

As herbal drugs are frequently contaminated by other plant parts from the same species, histological sections were made of the stems of $B$. forficata (in addition to the leaves) to evaluate if the samples contained only parts of that species or if they were contaminated by other materials from other plant taxa.

\section{Analysis of foreign materials}

Foreign materials were manually separated during visual inspection of the samples and then weighed separately to determine the contamination percentages. Foreign materials should not exceed an official limit of $2 \% \mathrm{~m} / \mathrm{m}$ (BRASIL, 2010).

\section{Results and discussion}

\section{Analysis of packaging and labeling}

The packaging was considered to be of moderate to low quality in terms of criteria of integrity and opacity. Seven of the ten sample packages analyzed were perforated by staples, which contributes to the contamination of the plant material and creates risks to consumer health. Additionally, $90 \%$ of the packages were made of entirely transparent material with no opacity, which subjects the plant material to degradation through exposure to light. According to Amaral et al. (2003), the low qualities of the herbal drugs often encountered by consumers are probably related to poor drying processes, inadequate storage conditions and low quality packaging. As such, our evaluations of the packaging indicated the probable degradation of the plant material in detriment to its conservation and medicinal efficiency, thus offering real risks to the consumer. A critical case was observed with sample 8, which did not even have a label, demonstrating the manufacturer's lack of concern for the consumer and the absence of any quality control, as the samples were not acquired in bulk. In this case, the consumer is not supplied with information that could guide him/her about the use of that product.

It can also be observed in Table 1 that there were wide variations between the weights declared on the packaging and their actual contents; for some samples, there was no information at all about content weight on the label. In three samples, the weights varied by more than $9 \%$ from declared 
weights, although only one of them was underweight. In one of the samples that weighed more than the declared value, $66 \%$ of the material was composed of stems, indicating falsification. Additionally, sample number 8 did not list any content weight at all, making it impossible to judge its conformity. According to Yokota et al. (2010), in addition to constituting consumer fraud, differences between the real and declared weights mean an absence or inefficiency of quality control by the manufacturers.

Table 1 - Analysis of the packages, labels and weights of the samples tested based on government criteria (RDC 10/10, RDC 14/16 and norms of INMETRO).

\begin{tabular}{ccccccc}
\hline Sample & $\begin{array}{c}\text { Integrity } \\
\text { (packaging) }\end{array}$ & $\begin{array}{c}\text { Opacity } \\
\text { (packaging) }\end{array}$ & $\begin{array}{c}\text { Declared weight } \\
\text { (label) }\end{array}$ & $\begin{array}{c}\text { Actual } \\
\text { weight }\end{array}$ & $\begin{array}{c}\text { Weight } \\
\text { variation }\end{array}$ & Foreign material \\
\hline $\mathbf{1}$ & Moderate & No & $10 \mathrm{~g}$ & $10.3196 \mathrm{~g}$ & $+3.19 \%$ & Branches and barks \\
$\mathbf{2}$ & Moderate & No & $20 \mathrm{~g}$ & $19.3166 \mathrm{~g}$ & $-3.41 \%$ & Branches \\
$\mathbf{3}$ & Low & No & $20 \mathrm{~g}$ & $22.3582 \mathrm{~g}$ & $+11.79 \%$ & Branches and fruit \\
$\mathbf{4}$ & Low & No & $15 \mathrm{~g}$ & $17.0300 \mathrm{~g}$ & $+13.53 \%$ & Branches \\
$\mathbf{5}$ & Moderate & Partial & $20 \mathrm{~g}$ & $20.4992 \mathrm{~g}$ & $+2.49 \%$ & Branches \\
$\mathbf{6}$ & Low & No & $20 \mathrm{~g}$ & $19.4452 \mathrm{~g}$ & $-2.77 \%$ & Branches \\
$\mathbf{7}$ & Low & No & $20 \mathrm{~g}$ & $19.8503 \mathrm{~g}$ & $-0.75 \%$ & Branches \\
$\mathbf{8}$ & High & No & Not indicated & $44.2505 \mathrm{~g}$ & - & Fruit \\
$\mathbf{9}$ & Moderate & No & $25 \mathrm{~g}$ & $23.3843 \mathrm{~g}$ & $-6.46 \%$ & Branches and fruit \\
$\mathbf{1 0}$ & Moderate & No & $30 \mathrm{~g}$ & $26.1640 \mathrm{~g}$ & $-12.78 \%$ & Branches and barks \\
\hline
\end{tabular}

Source: Elaborated by the authors (2015).

None of the 10 samples demonstrated conformity with all of the mandatory items specified by the previous RDC 10/10 and the current RDC 26/14 standards, this non-compliance represents a threat to consumer health due to the lack of even minimal instructions concerning the correct use of the product, side effects or any effects of its long-term use.

Sample 8 did not conform to any of the basic requirements: product name, plant parts utilized, manufacturer's name, government registry number, expiration date, lot number, barcode. In fully $50 \%$ of the samples, plant species was not declared, and only three of the samples correctly indicated the species $B$. forficata, as it is required by both RDC $10 / 10$ and RDC $26 / 14$. This same situation was observed by Engel et al. (2008), who reported only a single sample containing the correctly written scientific name of the plant sample. Melo et al. (2004) also found errors in the spelling of the genus and the specific epithet in samples of pata-de-vaca. A study by Nascimento et al. (2005) reported the lack of any scientific name on almost half of the samples they examined. The absence of the correct scientific name or indications for including plant parts may lead to adulteration and introduction of other plant organs that do not contain the desired active principles (or only contain them in very low quantities) (MELO et al., 2007). Therefore, encountering herbal drugs with correct labeling is a problem in many regions of Brazil.

Of the 38 mandatory phrases to be included in the labels by RDC 10/10 regulations, 11 were not included in any of the sample labels analyzed: "used to alleviate the symptoms of"; "therapeutic use; counter indications"; "use restrictions"; "adverse effects"; "it can be used without a medical prescription"; "if these symptoms persist, seek medical assistance"; "if this medication is to be used continuously, talk to your doctor beforehand"; "prepare the infusion or decoction immediately before taking it"; "herbal drugs should not be used for periods longer than indicated"; "the prolonged use of this product should be accompanied by a medical professional". 


\section{Macroscopic analyses}

\section{Morphology of the standard leaves}

The morphological characteristics of the standard leaf most relevant for the purposes of comparison and analysis with the commercial samples are described as follows: Bauhinia forficata Link has coriaceous leaves that are $8-12 \mathrm{~cm}$ long (FIGURE 1A). The leaves are divided into two lobes, with the central cleft extending one third or, more frequently, one half through the length of the leaf (FIGURE 1B). At the union of the two lobes, there is a mucro (FIGURE 1C). The leaf blade is symmetrical, with the adaxial surface glabrous and the abaxial surface pilose. The apices of the leaf lobes are acute, and the margins entire. The leaf base is slightly cordate. Venation pattern is actinodromous since each leaf has approximately nine veins that initiate radially from the same point and converge along the leaf borders to form a marginal venation. The vein in the region between the lobes is considered the midvein as Miyake, Akisue and Akisue (1986), Ellis et al. (2009) and Lin et al. (2015) even though it is thinner than the lateral veins.

Figure 1 - Macroscopic aspects of the B. forficata. A - Habitus. B - Bilobed leaf: lateral primary vein (Ipv) and midvein (mv). C - Detail of the mucro observed between the two lobes at the apex of the leaf. D -Proximal pulvinus (a), petiole (b) and distal pulvinus (c).
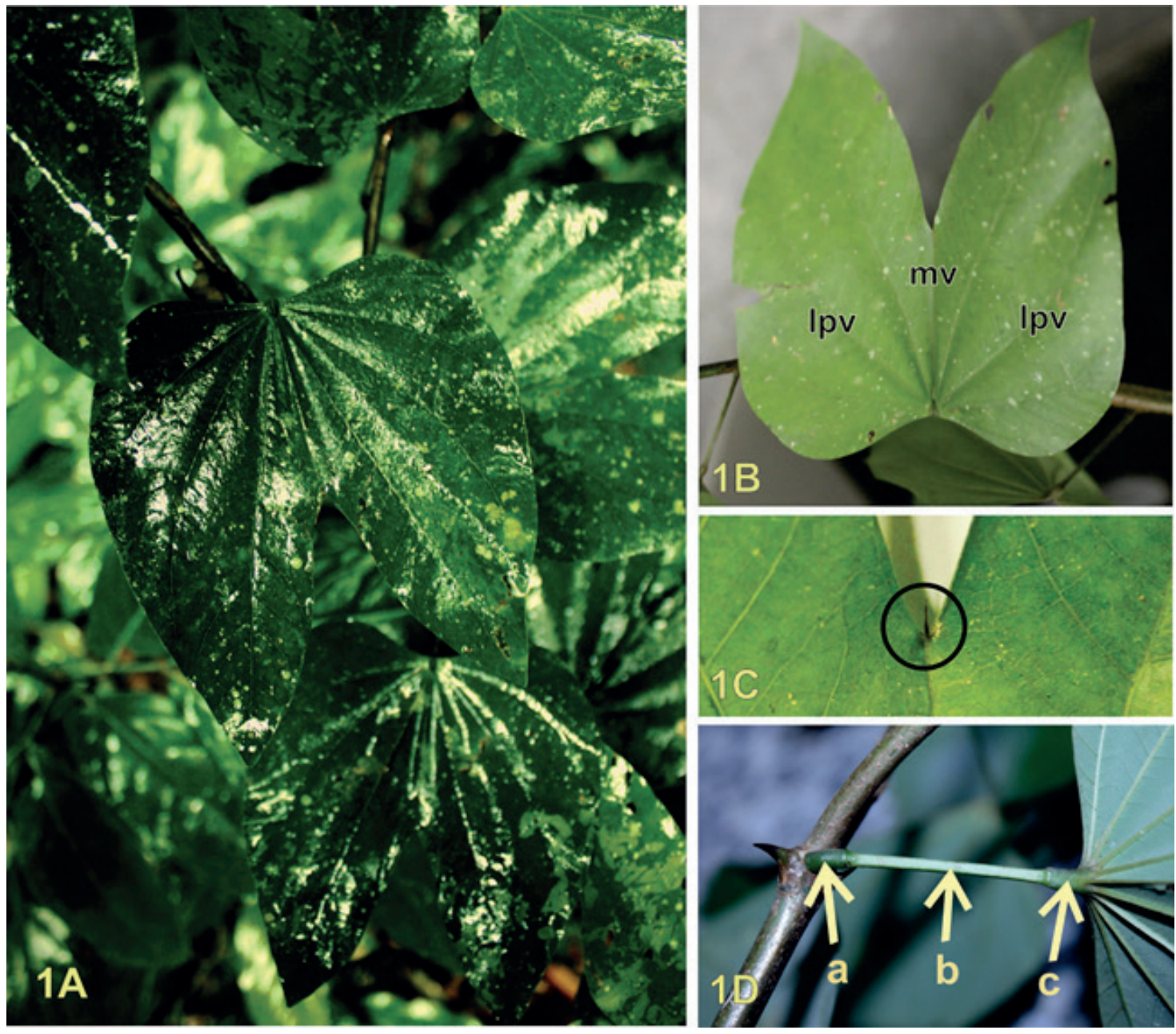

Source: Elaborated by the authors (2013). 


\section{Evaluations of the commercial samples}

In general, the samples were poorly conserved, demonstrating deterioration and in some cases alteration on odors and colors of the leaves (FIGURE 2A). Most of the packages contained entire leaves (FIGURE 2B) or fragments. Their morphological characteristics suggested the presence of species of the genus Bauhinia as they demonstrated the typical cow's hoof (pata-de-vaca) shape; however, their lobe apex is not acute (FIGURE 2C) as is the case in B. forficata (FIGURE 1B). Additionally, almost all of the samples had contaminants, even within the $2 \% \mathrm{~m} / \mathrm{m}$ limit permitted by the Brazilian Pharmacopeia. Sample 3 demonstrated the greatest percentage of contaminants (66\%), containing stem fragments, a fruit pod and, mainly, wood material. It was suggested those samples were adulterated with other species of Bauhinia or with other unknown plants, as it was observed in the present work. Likewise, Melo et al. (2004) reported that more than half of the samples of patade-vaca examined by them had excessive amounts of contaminant materials (a result also reported for other medicinal plants, such as boldo [Peumus boldus Molina]). An examination of contaminating materials undertaken by Amaral et al. (2003) revealed that $86 \%$ of the commercial samples contained impurities above the limits, such as foreign plant parts derived from the same species, living or dead insects and inert contaminants such as soil, sand and pebbles. These contaminants are similar to those found in this study. As such, excessive quantities of contaminants represent a common problem not just for $B$. forficata, but, probably, for all species commercialized as herbal drugs (NASCIMENTO et al., 2005; MACRINI, 2011; COSTA; GUIMARÃES; VIEIRA, 2014).

Figure 2 - Macroscopic aspects of some samples.
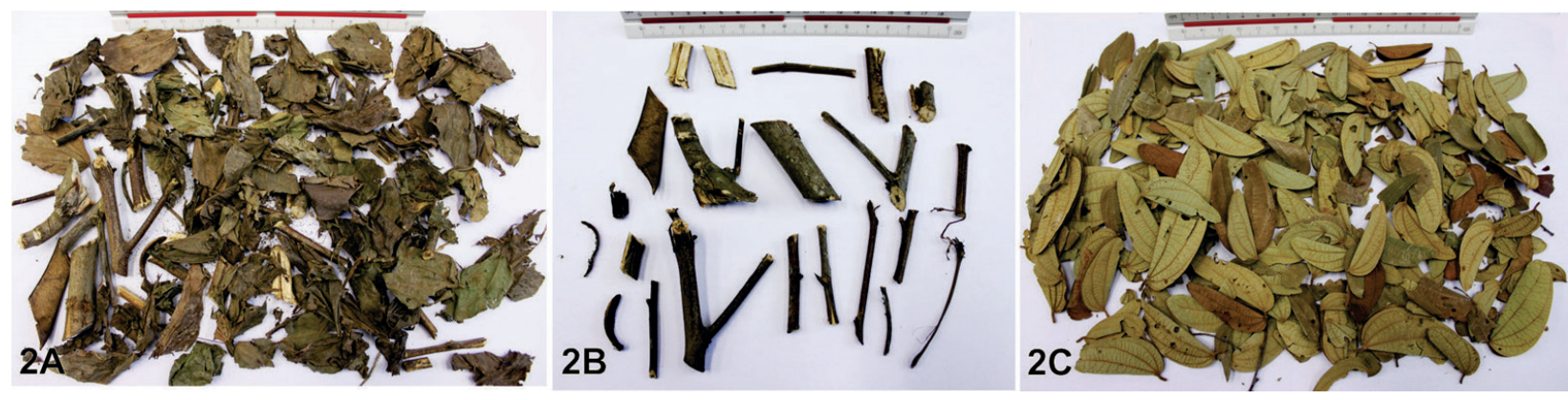

A-B - Sample 3 - Note the presence of the degraded material, making macroscopic identification difficult due to its state of conservation (A) and foreign material (B). C - Entire leaves that resemble those of the genus Bauhinia in good state of conservation (Sample 5).

Source: Elaborated by the authors (2014).

The contaminants encountered in our samples (and reported in other studies) probably reflect the processes of raw product management, sanitation, and inadequate separation of the plant material - problematic factors that have often been observed in medicinal plant products (AMARAL et al., 2003). 


\section{Microscopic analyses}

\section{Leaf anatomy of the Bauhinia forficata Link standard}

The anatomical characteristics of the standard leaf most relevant for comparison and analysis with the commercial samples are described as follows: The leaf blade epidermis, in frontal view, is glabrous and has trichomes near the veins in the adaxial face. The abaxial face shows the presence of unicellular and multicellular uniseriate tector trichomes (FIGURE 3A), as well as multicellular glandular navicular trichomes (FIGURE 3B).

The midvein, in transverse section, has a concave-convex to flat-convex profile (FIGURE 3C). The epidermis is unistratified and composed of rounded cells. Approximately five parenchyma layers can be observed below the adaxial face of the epidermis; two collenchyma and two parenchyma layers occur below the abaxial face. The collateral vascular bundle in the central region of the leaf is surrounded by a sheath of sclerenchyma.

The lateral primary vein, in transverse section, showed a flat-convex profile, and was greater in diameter than the midvein (FIGURE 3E). The epidermis on both faces was similar to the epidermis on the rest of the blade, although composed of cells of smaller dimensions. On the adaxial face, 2 layers of palisade parenchyma cells are interrupted by collenchyma cells. On the abaxial face, in a sub-epidermal position, from 1 to 2 layers of collenchyma and from 1 to 2 layers of fundamental parenchyma could be observed. The vascular bundle demonstrated the same histological organization observed in the midvein.

The petiole has a generally rounded outline when viewed in transverse section, although it becomes flattened in the anterior-posterior direction, with two lateral projections on the adaxial face (FIGURE 3F); these lateral projections each contain a collateral vascular bundle wrapped in a complete (although asymmetric) sheath of sclerenchyma. The epidermis is uniseriate, composed of diminutive, rounded cells covered by a thick cuticle with tector and glandular trichomes, as observed on the leaf blade (FIGURE 3D). On the adaxial face there are 4 to 5 layers of fundamental parenchyma, and the sub-epidermis of the abaxial face has 2 to 3 layers of collenchyma and 3 of parenchyma. Two collateral vascular bundles occupy the center region of the petiole, which can unite and form a continuous ring covered by a sheath of gelatinous fibers for almost its entire length. The pith is occupied by fundamental parenchyma composed of isodiametric cells of varying sizes, with idioblasts containing druses. 
Figure 3. Light microscopy of the leaf of Bauhinia forficata standard.

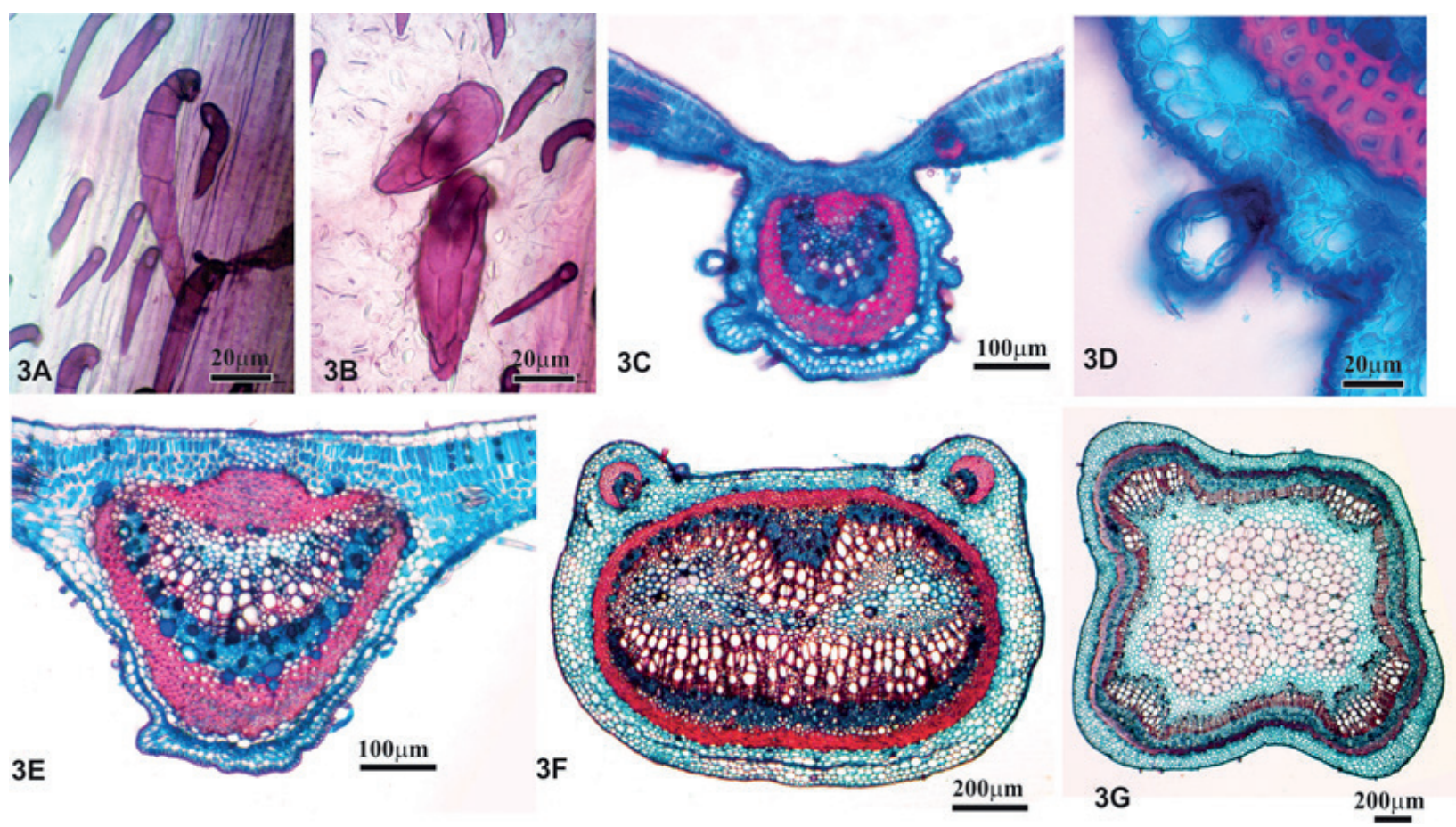

A-B - FV- Epidermis on the abaxial face: unicellular and multicellular unistratified tector trichomes $(A)$ and glandular navicular trichomes (B); C - TS- MV: general aspect; D - TS- MV: Detail of the navicular trichome; E - TS- LPV: general aspect; F - TS- Petiole: general aspect; J - TS- stem initiating secondary growth. FV- Frontal view; LPV- Lateral primary vein; MV- Midvein; TS- Transverse section.

Source: Elaborated by the authors (2015).

\section{Stem anatomy of $B$. forficata standard}

The stem appears quadrangular in transverse section, with incipient secondary growth at the level analyzed (FIGURE 3J). The epidermis is uniseriate, with rounded cells, and is covered by a thick cuticle with tector and glandular trichomes, as observed on the leaf blade. The cortical region has 4 to 8 collenchyma layers and 2 chlorophyllous parenchyma layers. The vascular system, in its primary structure, is of the eustele type, with collateral vascular bundles. In its secondary structure, the vascular system forms a complete ring delimited externally by sclerenchyma fibers, some of which are gelatinous. The pith is occupied by fundamental parenchyma composed of isodiametric cells of varying sizes, with idioblasts containing druses.

\section{Evaluations of the commercial samples}

In spite of the fact that the 10 commercial samples analyzed here were found to have botanical material identified as belonging to the genus Bauhinia, only sample 3 had leaves with anatomical characteristics similar to the $B$. forficata standard as described by Miyake, Akisue and Akisue (1986), Donato (1995), Lusa and Bona (2009) and to the standard leaves described here; we did, however, find leaves identified as being from other species in that same sample 3 . Note that the lateral vein (FIGURE 4A) and the petiole (FIGURE 4B) demonstrate histological organization similar to the standard (FIGURES $3 \mathrm{H}, 3 \mathrm{I}$ ). However, the excessive numbers of druses in the cortical region 
in one of the histological sections of the midrib (FIGURE 5B) suggest that the sample is not pure. Similar results were reported by Engel et al. (2008) in their analyses, with only two of the samples demonstrating anatomical characteristics compatible with $B$. forficata and, again, essentially all the samples analyzed by them were identified as having contaminating material.

Figure 4. Aspect of material found in sample 3. The anatomical analysis revealed the sample's similarity to the standard material.
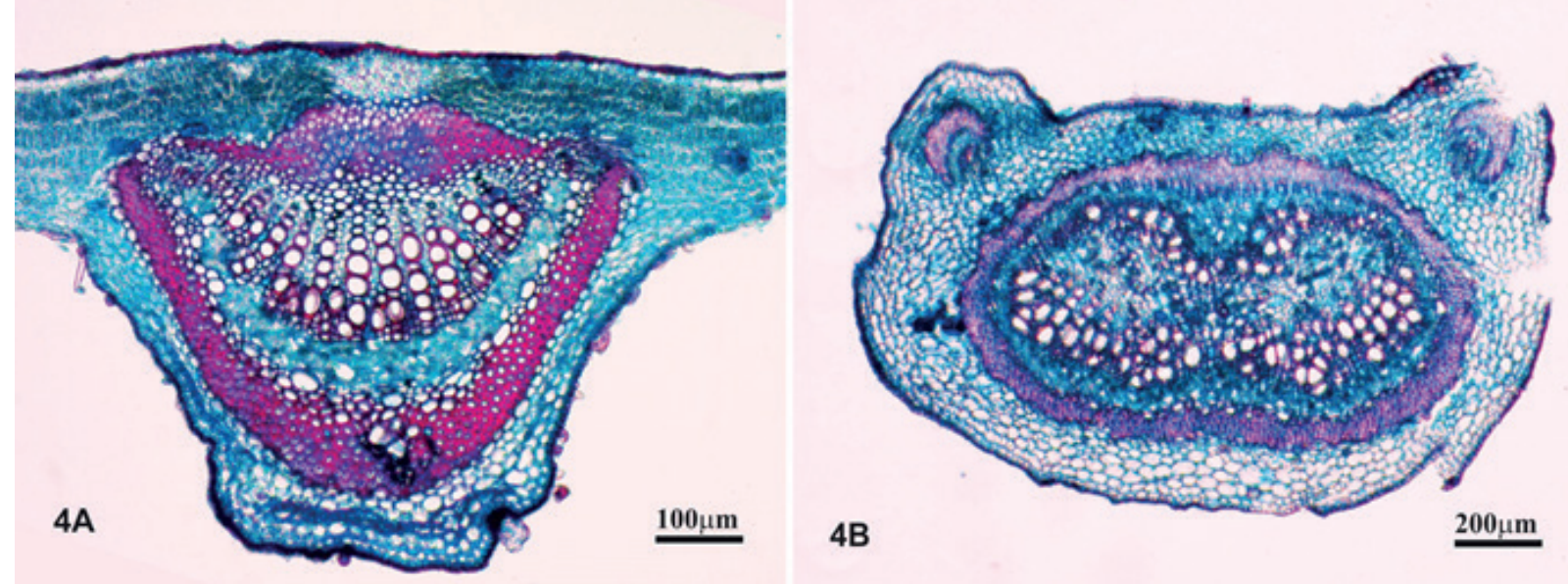

A - TS- Lateral primary vein; B - TS- Petiole. TS- Transverse section.

Source: Elaborated by the authors (2015).

Diverse anatomical characteristics observed in the midvein and lateral primary vein of the sample leaves indicated the inclusion of other species of the genus Bauhinia or even other families. Leaves with histological organizations typical of the family Poaceae (grasses) were observed in sample 1 (FIGURE 5A). We observed: excesses of trichomes on the epidermis of samples 5 and 6 (FIGURE $5 D$ ), cortical parenchyma with greater numbers of cell layers and much smaller xylem/phloem ratios in samples 4, 7 and 9 (FIGURE 5C), vein outlines with elliptical shapes in samples 1, 2, 5, 6 and 10 (FIGURE 5D), greater numbers of cell layers in the cortical parenchyma on the abaxial face, sclerenchymatous bundle sheath extensions on the adaxial face of sample 8 (FIGURE 5F), and a general histological organization very distinct from the standard in sample 7 (FIGURE 5E).

The petioles of samples 4, 7, 8 and 10 demonstrated characteristics similar to those of the genus Bauhinia, although they did not correspond to the vascular bundle organization of the $B$. forficata standard, nor to the histological organization of its petiole (FIGURES 6A and 6B). The presence of stems in the samples demonstrated contamination, and the stems of samples 4, 5, 6 and 9 did not belong to the standard Bauhinia species due to the histological organization different from that of the standard and excessive quantities of trichomes (FIGURES 6C and 6D).

Though the standard leaves and the commercial samples are morphologically similar, the anatomical characteristics found in the samples deviate from those described as belonging to $B$. forficata in both the literature (MIYAKE; AKISUE; AKISUE (1986), Donato (1995), Lusa and Bona (2009)) and the anatomical description carried out in this study. The parts of the B. forficata leaf most useful in the analysis were the mid and lateral veins and the petiole, not only due to the vascular organization so characteristic of the standard leaf, but because these elements were better conserved in the samples and thus easier to handle. 
According to Martins and Figueiredo (2009), the quality of herbal drugs in the marketplace will depend in large part on their production systems. The harvesting of wild plants is the main source of herbal drugs commercialized in Brazil today. A significant portion of these drugs available for sale in that country is of inferior quality, with problems that include contamination, altered phytochemical profiles and unreliable botanical identifications. Additionally, harvesting in the wild threatens many natural plant populations (MARTINS; FIGUEIREDO, 2009) and demonstrates a disconnection between the manufacturers and the sustainable production of those herbal drugs. The macroscopic similarities of the leaves of various species of Bauhinia favor the adulteration of herbal drugs and other plant products, as $B$. forficata leaves are obtained by harvesting non-cultivated plants (AZEVEDO; SILVA, 2006). B. forficata is, however, a pioneer species that can grow well under full sunlight in open areas, a characteristic that would allow the use of cultivation strategies as reasonable alternatives to harvesting its leaves in the field (REIS; MARIOT; STEENBOCK, 2010), which would decrease falsification.

Figure 5. TS - Anatomical aspect of materials found in the different analyzed samples, including the presence of contaminants. When comparing the sample veins (TS) to those of $B$. forficata, none of them fit the standard.

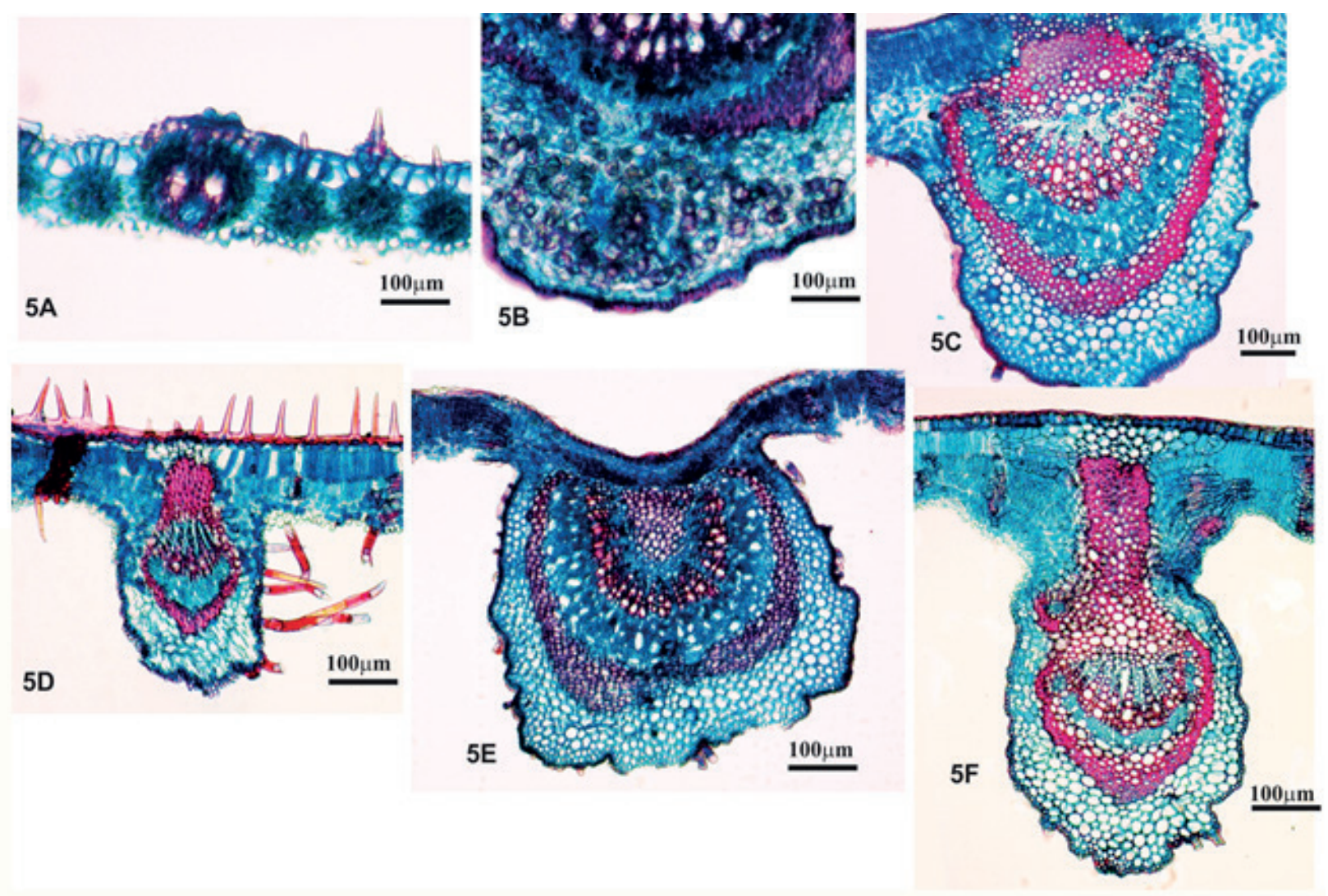

A - Sample 1: Contaminant with histological organization similar to that of the Poaceae family; B - MV - Sample 3: Excessive quantities of druses; C - LPV - Sample 4: Histological organization different from that of the standard; D - LPV - Sample 6: Excessive quantities of tector trichomes on the adaxial face; E - MV - Sample 7 and F - LPV - Sample 8: Histological organization different from that of the standard. LPV - Lateral primary vein. MV - Midvein. TS- Transverse section.

Source: Elaborated by the authors (2015). 
Figure 6. General aspect of petioles and stems in transverse section found in the analyzed samples.
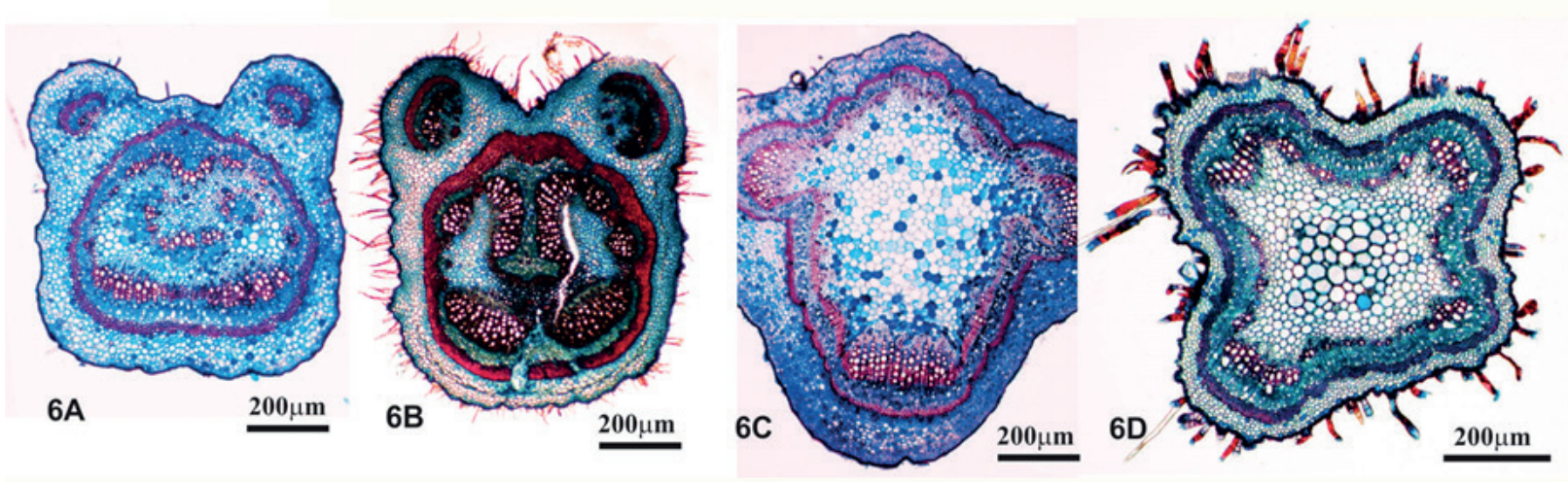

A-B - Sample petioles: note the histological organizations typical of the genus Bauhinia, although not similar to the standard. Sample 4 (A) and sample 8 (B); C-D - Stems of the samples: note the histological organizations that differ from the standard. Sample 4 (C) and sample 5 (D).

Source: Elaborated by the authors (2015).

Because herbal drugs are widely sold throughout Brazil and easy to acquire, there is an overwhelming need for more intensive monitoring and control of their quality. This species has been the focus of a wide variety of studies that have demonstrated its therapeutic usefulness, however little information is available concerning the toxicity of this remedy. Studies of this type will be extremely necessary, especially because pata-de-vaca is a popular traditional native medicinal plant in Brazil with widely known pharmacological effects.

\section{Conclusions}

Of the 10 samples analyzed, none demonstrated the required quality for herbal drugs. All of them were deficient in terms of their packaging, and their labeling lacked the required information and/ or provided erroneous data. Additionally, only one sample had leaves with anatomical characteristics of $B$. forficata, and essentially all samples contained various types of contaminants.

\section{Acknowledgments}

The authors thank PET-Farmácia for the study grant.

\section{Avaliações da qualidade do "pata-de-vaca" (Bauhinia forficata Link) vendido no Brasil}

\section{Resumo}

O gênero Bauhinia L. (Leguminosae), conhecido popularmente como pata-de-vaca, apresenta ampla diversidade no território brasileiro, compreendendo tanto espécies nativas quanto espécies exóticas. A espécie mais conhecida na medicina popular, Bauhinia forficata Link, denominada "patade-vaca verdadeira", é uma arvoreta cujas folhas são utilizadas sob forma de infusão para o tratamento 
da diabetes. Como as espécies do gênero Bauhinia apresentam folhas bilobadas, essa semelhança contribui fortemente para a falsificação de produtos tradicionais fitoterápicos que deveriam ser constituídos de folha de Bauhinia forficata. Foram adquiridas 10 amostras comerciais de diferentes fabricantes de "pata-de-vaca" que a comercializam sob a forma de droga vegetal em várias regiões do Brasil e foram analisadas sob aspectos macro e microscópicos. Para fins comparativos, realizou-se o estudo morfoanatômico da folha da espécie padrão e analisou-se a literatura científica. Os pacotes e os rótulos foram avaliados baseados nas normatizações da ANVISA. Quase todas as amostras tinham caracteres anatômicos diferentes da folha padrão indicando que não eram autênticas. Ademais, todos os pacotes continham contaminantes. Assim, os resultados obtidos mostraram que todas as amostras analisadas foram reprovadas quanto aos aspectos avaliados. Esse tipo de produto, além de lesar o consumidor, ocasiona um risco significativo à saúde da população.

Palavras-chave: Chá medicinal. Controle de qualidade. Droga vegetal. Fabaceae. Plantas medicinais. Produto tradicional fitoterápico.

\section{References}

ANVISA. AGÊNCIA NACIONAL DE VIGILÂNCIA SANITÁRIA. Farmacopeia Brasileira, v. 1. 5. ed. Brasília, 2010. Disponível em: http://portal.anvisa.gov.br/documents/33832/260079/5ª+edição++Volume+1/4c530f86-fe83-4c4a-b907-6a96b5c2d2fc. Acesso em: 12 maio 2015.

AMARAL, F. M. M.; COUTINHO, D. F.; RIBEIRO, M. N. S.; OLIVEIRA, M. A. Avaliação da qualidade de drogas vegetais comercializadas em São Luís/ Maranhão. Revista Brasileira de Farmacognosia, Maringá, v. 13, supl.1, p. 27-30, 2003. Disponível em: http://www.scielo.br/pdf/rbfar/v13s1/ a11v13s1.pdf. Acesso em: 17 mar. 2014.

AZEVEDO, S. K. S.; SILVA, I. M. Plantas medicinais e de uso religioso comercializadas em mercados e feiras livres no Rio de Janeiro, RJ, Brasil. Acta Botanica Brasilica. v. 20, n. 1, p. 185-194, 2006. Disponível em: http://www.scielo.br/scielo.php?script=sci_arttext\&pid=S0102$33062006000100017 \&$ Ing=en. Acesso em: 11 dez. 2013.

BALBINO, E. E.; DIAS, M. F. Farmacovigilância: um passo em direção ao uso racional de plantas medicinais e fitoterápicos. Revista Brasileira de Farmacognosia, v. 20, n. 6, p. 992-1000, dez. 2010. Disponível em: http://www.scielo.br/scielo.php?script=sci_arttext\&pid=S0102695X2010000600027\&lng=en. Acesso em: 09 abr. 2014.

BALBINOT, S.; VELASQUEZ, P. G.; DÜSMAN, E. Reconhecimento e uso de plantas medicinais pelos idosos do Município de Marmeleiro - Paraná. Revista Brasileira de Plantas Medicinais. v. 15, n. 4, p. 632-638, 2013. Disponível em: http://www.scielo.br/scielo.php?script=sci_arttext\&pid=S1516$05722013000500002 \&$ Ing =en. Acesso em: 09 set. 2015.

BOSCOLO, O. H.; VALLE, L. S. Plantas de uso medicinal em Quissamã, Rio de Janeiro, Brasil. Iheringia, Sér Bot. v. 63, n. 2, p. 263-277, 2008. Disponível em: http://www.fzb.rs.gov.br/ upload/20140328114019ih63_2_p263_278.pdf. Acesso em: 09 abr. 2014. 
BRASIL. Ministério do Desenvolvimento, Indústria e Comércio Exterior. Instituto Nacional de Metrologia, Normalização e Qualidade Industrial. Portaria n 248, de 17 de julho de 2008. Dispõe sobre os critérios para verificação do conteúdo líquido de produtos pré-medidos com conteúdo nominal igual, comercializado nas grandezas de massa ou volume. 2008. Disponível em: http://www.inmetro.gov. br/legislacao/rtac/pdf/RTAC001339.pdf. Aceso em: 10 mar. 2015.

BRASIL. A fitoterapia no SUS e o Programa de Pesquisa de Plantas Medicinais da Central de Medicamentos. Brasília, Ministério da Saúde, 2006. Disponível em: http://bvsms.saude.gov.br/bvs/ publicacoes/fitoterapia_no_sus.pdf. Acesso em: 10 mar. 2015.

BRASIL. Ministério da Saúde. MS elabora Relação de Plantas Medicinais de Interesse ao SUS. Portal da Saúde, 06 mar. 2009 Disponível em: http://bvsms.saude.gov.br/bvs/sus/pdf/marco/ms_ relacao_plantas_medicinais_sus_0603.pdf. Acesso em: 05 maio 2015.

BRASIL. Agência Nacional de Vigilância Sanitária (ANVISA). Resolução de diretoria colegiada $\mathrm{n}^{0}$ 10, de 9 de março de 2010. Notificação de drogas vegetais junto à Agência Nacional de Vigilância Sanitária (ANVISA) e dá outras providências. 2010. Disponível em: http://portal.anvisa. gov.br/documents/10181/2718376/RDC_10_2010_COMP.pdf/6d4feca0-9b45-48f8-b44e231fa048e4a6. Acesso em: 16 maio 2013

BRASIL. Ministério da Saúde. Agência Nacional de Vigilância Sanitária. Resolução de diretoria colegiada $n^{\circ} 26$ de 13 de maio de 2014. Dispõe sobre registro de medicamentos fitoterápicos e o registro e a notificação de produtos tradicionais fitoterápicos. 2014. Disponível em: http://portal. anvisa.gov.br/documents/10181/3171284/\%283\%29RDC_26_2014_COMP.pdf/84bee0e4-6504461d-b672-77b088898e2d. Acesso em: 10 mar. 2015.

BUKATSCH, F. Bemerkungen zur Doppelfärbung Astrablau-Safranin. Mikrokosmos, v. 61, p. 255, 1972.

CAPASSO, R.; IZZO, A. A.; PINTO, L.; BIFULCO, T.; VITOBELLO, C.; MASCOLO, N. Phytotherapy and quality of herbal medicines. Fitoterapia, v. 71, n. 1, p. S58-S65, ago. 2000. Disponível em: https://www. sciencedirect.com/science/article/pii/S0367326X00001738/pdfft?md5=82bfdada3ed206248583129 57ec35029\&pid=1-s2.0-S0367326X00001738-main.pdf. Acesso em: 22 out. 2014.

CAZAROLLI, L. H.; ZANATTA, L.; JORGE, A. P.; SOUSA, E.; HORST, H.; WOEHL, V. M.; PIZZOLATTI, M. G.; SZPOGANICZ, B.; SILVA, F. R. M. B. Follow-up studies on glycosylated flavonoids and their complexes with vanadium their anti-hyperglycemic potential role in diabetes. Chemico-Biological Interactions, v. 163, p. 177-191, Jul. 2006. Disponível em: https://www.sciencedirect.com/science/ article/pii/S0009279706002092/pdfft?md5=a1a6529b6c826830c3fb4e6bcf1 ba0c8\&pid=1 s2.0-S0009279706002092-main.pdf. Acesso em: 26 set. 2014.

CAZAROLLI, L. H.; FOLADOR, P.; PIZZOLATTI, M. G.; SILVA, F. R. M. B. Signaling pathways of kaempferol-3-eohesperidoside in glycogen synthesis in rat soleus muscle. Biochimie, v. 91, p. 843-849, abr. 2009. Disponível em: https:/www.sciencedirect.com/science/article/pii/S030090840900100X/ pdfft?md5=0298968ecbaf2d65fe346f40dbc83c4c\&pid=1-s2.0-S030090840900100X-main. pdf. Acesso em: 26 set. 2014. 
COSTA, R. P. C.; GUIMARÃeS, A. L. A.; VIEIRA, A. C. M. Avaliação da qualidade de amostras de plantas medicinais comercializadas no Brasil. Revista de Ciências Farmacêuticas Básica e Aplicada, v. 35, n. 3, p. 425-433, 2014. Disponível em: http://serv-bib.fcfar.unesp.br/seer/index.php/Cien_ Farm/article/viewFile/3001/1607. Acesso em: 02 jun. 2015.

CUNHA-LIMA, S. T.; RODRIGUES, E. D.; MELO, T.; NASCIMENTO, A. F.; GUEDES, M. L. S.; CRUZ, T.; ALVES, C.; MEYER, R.; TORALLES, M. B. Levantamento da flora medicinal usada no tratamento de doenças metabólicas em Salvador, BA- Brasil. Revista Brasileira de Plantas Medicinais, v. 10, n. 4, p. 83-89, 2008. Disponível em: http://www.sbpmed.org.br/download/issn_08_4/artigo12_p8389.pdf. Acesso em: 10 mar. 2015.

DEFANI, M. A.; BARBOSA, T. K.; ROSSI, S. L.; NASCIMENTO, R. C. Utilização das plantas medicinais por diabéticos do município de Goioerê-PR. Saúde e Pesquisa, v. 4, n. 2, p. 223-231, 2011 . Disponível em: http://periodicos.unicesumar.edu.br/index.php/saudpesq/article/download/1871/1280. Acesso em: 09 abr. 2014.

DI STASI, L. C.; HIRUMA-LIMA, C. A. Plantas medicinais na Amazônia e na Mata Atlântica. 2. ed. São Paulo, Editora UNESP, 2002.

DI STASI, L. C.; OLIVEIRA, G. P.; CARVALHAES, M. A.; QUEIROZ-JUNIOR, M.; TIENA, O. S.; KAKINAMIA, S. H.; REISB, M. S. Medicinal plants popularly used in the Brazilian Tropical Atlantic Forest. Fitoterapia, v. 73, p. 69-91, 2002. Disponível em: https://www.sciencedirect.com/science/ article/pii/S0367326X01003628/pdfft?md5=c5893a7f66e035d880ecacbb57703a22\&pid=1 s2.0-S0367326X01003628-main.pdf. Acesso em: 23 nov. 2015.

DONATO, A. M. Anatomia foliar e abordagem fitoquímica de Bauhinia forficata Link. (LeguminosaeCaesalpinioideae). Bradea, v. 6, n. 42, p. 357-371, 1995.

ELLIS, B.; DALY, D. C.; HICKEY, L. J.; JOHNSON, K. R.; MITCHELL, J. D.; WILF, P.; SCOTT, L. Manual of Leaf Architecture. Ithaca Cornell University Press, 2009.

ENGEL, I. C.; FERREIRA, R. A.; CECHINEL-FILHO, V.; MEYRE-SILVA, C. Controle de qualidade de drogas vegetais a base de Bauhinia forficata Link (Fabaceae). Revista Brasileira de Farmacognosia, v. 18, n. 2, p. 258-264, abr./jun. 2008. Disponível em: http://www.scielo.br/pdf/rbfar/v18n2/21.pdf. Acesso em: 17 mar. 2014.

FRANKLIN, G. L. Preparation of thin sections of synthetic resins and wood-resin composites, and a new macerating method for wood. Nature, v. 155, p. 51, 1945.

HAVSTEEN, B. H. The biochemistry and medical significance of the flavonoids. Pharmacology \& Therapeutics, v. 96, n. 2, p. 67-202, 2002. Disponível em: https://www.sciencedirect.com/science/ article/pii/S016372580200298X/pdfft?md5=61 aaa7eeb5e1f6ff9c882f7bcfbcd1 ed\&pid=1-s2.0S016372580200298X-main.pdf. Acesso em: 15 ago. 2014.

HOWARTH, W.; WARNE, L. G. G. Practical Botany for the Tropics. London: Univ. of London Press. 1959. 
LIN, Y.; WONG, W. O.; SHI, G.; SHEN, S.; LI, Z. Bilobate leaves of Bauhinia (Leguminosae, Caesalpinioideae, Cercideae) from the middle Miocene of Fujian Province, southeastern China and their biogeographic implications. BMC Evolutionary Biology, v. 15, p. 1-17, 2015. Disponível em: https:// bmcevolbiol.biomedcentral.com/track/pdf/10.1186/s12862-015-0540-9. Acesso em: 14 jun. 2016.

LINO, C. S.; DIÓGENES, J. P. L.; PEREIRA, B. A.; FARIA, R. A. P. G.; ANDRADE NETO, M.; ALVES, R. S.; QUEIROZ, M. G. R.; SOUSA, F. C. F.; VIANA, G. S. B. Antidiabetic activity of Bauhinia forficata extracts in Alloxan-diabetic rats. Biological and Pharmaceutical Bulletin, v. 27, n. 1, p. $125-127$, 2004. Disponível em: https://www.jstage.jst.go.jp/article/bpb/27/1/27_1_125/_pdf/-char/en. Acesso em: 26 set. 2014.

LORENZI, H.; MATOS, F. J. A. Plantas medicinais no Brasil: nativas e exóticas. 2. ed. Nova Odessa: Plantarum, 2008.

LUSA, M. G.; BONA, C. Análise morfoanatômica comparativa da folha de Bauhinia forficata Link e B. variegata Linn. (Leguminosae, Caesalpinioideae). Acta Botanica Brasilica, v. 23, n. 1, p. 196 211, mar. 2009. Disponível em: http://www.scielo.br/pdf/abb/v23n1/v23n1a22.pdf. Acesso em: 11 dez. 2013

MACRINI T. Análise farmacognóstica de amostras de drogas vegetais psicoativas comercializadas em Diadema. São Paulo, 2011. 123f. Dissertação (Mestrado)- Universidade de São Paulo, São Paulo, 2011.

MARQUES, G. S.; MONTEIRO, R. P. M.; LEÃO, W. F.; LYRA, M. A. M.; PEIXOTO, M. S.; ROLIMNETO, P. J.; XAVIER, H. S.; SOARES, L. A. L. Avaliação de procedimentos para quantificação espectrofotométrica de flavonoides totais em folhas de Bauhinia forficata Link. Química Nova, v. 35, n. 3, p. 517-522, 2012. Disponível em: http://www.scielo.br/pdf/qn/v35n3/14.pdf. Acesso em: 21 ago. 2013.

MARTINS, E. R.; FIGUEIREDO, L. S. Cultivo de plantas medicinais. In: LEITE, J. P. V. Fitoterapia: bases científicas e tecnológicas. São Paulo: Atheneu, 2009. p. 143-167.

MELO, J. G.; NASCIMENTO, V. T.; AMORIM, E. L. C.; ANDRADE-LIMA, C. S.; ALBUQUERQUE, U. P. Avaliação da qualidade de amostras comerciais de boldo (Peumus boldus Molina), pata-de-vaca (Bauhinia spp.) e ginco (Ginkgo biloba L.). Revista Brasileira de Farmacognosia, v. 14, n. 2, jul./dez. 2004. Disponível em: http://www.scielo.br/pdf/rbfar/v14n2/a04v14n2.pdf. Acesso em: 21 ago. 2013.

MELO, J. G; MARTINS, J. D. G. R.; AMORIM, E. L. C.; ALBUQUERQUE, U. P. Qualidade de produtos a base de plantas medicinais comercializados no Brasil: castanha-da-índia (Aesculus hippocastanum L.), capim-limão (Cymbopogon citratus (DC.) Stapf ) e centela (Centella asiatica (L.) Urban). Acta Botanica Brasilica, v. 21, n. 1, p. 27-36, 2007. Disponível em: http://www.scielo.br/pdf/abb/ v21n1/04.pdf. Acesso em: 09 abr. 2014.

MENEZES, F. S.; MINTO, A. B. M.; RUELA, H. S.; KUSTER, R. M.; SHERIDAN, H.; FRANKISH, N. Hypoglycemic activity of two Brazilian Bauhinia species: Bauhinia forficata L. and Bauhinia monandra Kurz. Revista Brasileira de Farmacognosia, v. 17, n. 1, p. 08-13, jan./mar. 2007. Disponível em: http://www.scielo.br/pdf/rbfar/v17n1/a03v17n1.pdf. Acesso em: 21 ago. 2013 
MIYAKE, E. T.; AKISUE, G.; AKISUE, M. K. Caracterização farmacognóstica da Pata-de-vaca Bauhinia forficata Link. Revista Brasileira de Farmacognosia, v. 1, n. 1, p. 58-68, 1986. Disponível em: http://www.scielo.br/pdf/rbfar/v1n1/a07v1n1.pdf. Acesso em: 03 set. 2013.

NASCIMENTO, V. T.; LACERDA, E. U.; MELO, J. G.; LIMA, C. S. A.; AMORIM, E. L. C.; ALBUQUERQUE, U. P. Controle de qualidade de produtos à base de plantas medicinais comercializados na cidade do Recife-PE: erva-doce (Pimpinella anisum L.), quebra-pedra (Phyllanthus spp.), espinheira santa (Maytenus ilicifolia Mart.) e camomila (Matricaria recutita L.). Revista Brasileira de Plantas Medicinais. v. 7, n. 3, p. 56-64, 2005. Disponível em: http://www.sbpmed.org.br/download/ issn_05_3/artigo8_v7_n3.pdf. Acesso em: 09 abr. 2014.

PANTOJA, S. C. S.; LOPES, G. F. G. Levantamento das espécies de plantas medicinais utilizadas pela população de Santa Cruz - Rio de Janeiro - RJ. Revista Eletrônica Novo Enfoque. v. 15, p. 62-68, 2012. Acesso em: 09 set. 2015.

PEIXOTO-SOBRINHO, T. J. S.; GOMES, T. L. B.; CARDOSO, K. C. M.; ALBUQUERQUE, U. P.; AMORIM, E. L. C. Teor de flavonóides totais em produtos contendo pata-de-vaca (Bauhinia L.) comercializados em farmácias de Recife. Revista Brasileira de Plantas Medicinais, v. 14, n. 4, p. 586-591, 2012. Disponível em: http://www.scielo.br/pdf/rbpm/v14n4/03.pdf. Acesso em: 21 ago. 2013.

REIS, M. S.; MARIOT, A.; STEENBOCK, W. Diversidade e domesticação de plantas medicinais. In: SIMÕES, C. M. O. Farmacognosia: da planta ao medicamento. 6. ed. Florianópolis: Editora UFSC, 2010. p. 45-74.

RUSSO, E. M.; REICHELT, A. A.; SÁ, J. R.: FURLANETTO, R. P.; MOISÉS, R. C.; KASAMATSU, T. S.; CHACRA, A. R. Clinical trial of Myrcia uniflora and Bauhinia forficata leaf extracts in normal and diabetic patients. Revista Brasileira de Pesquisas Médicas e Biológicas, v. 23, n. 1, p. 11-20, 1990. Disponível em: https://www.ncbi.nlm.nih.gov/pubmed/2201413. Acesso em: 10 abr. 2013.

SALATINO, A.; BLATT, C. T. T.; SANTOS, D. Y. A. C.; VAZ, A. M. S. F. Foliar flavonoids of nine species of Bauhinia. Revista Brasileira de Botânica, v. 22, n. 1, abr. 1999. Disponível em: http://www. scielo.br/scielo.php?script=sci_arttext\&pid $=$ S0100-84041999000100003\&lng =en\&nrm $=i s o \& t / n$ g=en. Acesso em: 21 ago. 2013.

SILVA, K. L; CECHINEL-FILHO, V. Plantas do gênero Bauhinia: composição química e potencial farmacológico. Química Nova, v. 25, n. 3, p. 449-454, set. 2002. Disponível em: http://www.scielo. br/pdf/qn/v25n3/9339.pdf. Acesso em: 21 ago. 2013.

SILVA, F. R. M. B.; SZPOGANICZ, B.; PIZZOLATTI, M. G.; WILLRICH, M. A. V.; SOUSA, E. Acute effect of Bauhinia forficata on serum glucose levels in normal and alloxan-induced diabetic rats. Journal of Ethnopharmacology, v. 83, p. 33-37, jul. 2002. Disponível em: https://www.sciencedirect.com/ science/article/pii/S0378874102001939/pdfft?md5=2bfb39eef661d7f9f581830e07c41e6c\&p id=1-s2.0-S0378874102001939-main.pdf. Acesso em: 03 set. 2013. 
SILVEIRA, P. F.; BANDEIRA, M. A. M.; ARRAIS, P. S. D., Farmacovigilância e reações adversas às plantas medicinais e fitoterápicos: uma realidade. Revista Brasileira de Farmacognosia, v. 18, $\mathrm{n}$. 4, p. 618-626, out./dez. 2008. Disponível em: http://www.scielo.br/pdf/rbfar/v18n4/v18n4a21.pdf. Acesso em: 09 abr. 2014.

SOUSA, E.; ZANATTA, L.; SEIFRIZ, I.; CRECZYNSKI-PASA, T. B.; PIZZOLATTI, M. G.; SZPOGANICZ, B.; SILVA, F. R. M. B. Hypoglycemic Effect and Antioxidant Potential of Kaempferol-3,7-0-(r)dirhamnoside from Bauhinia forficata leaves. Journal of Natural Products, v. 67, n. 5, p. 829-832, abr. 2004. Disponível em: https://pubs.acs.org/doi/abs/10.1021/np030513u. Acesso em: 21 ago. 2013.

SOUZA-MOREIRA, T. M.; SALGADO, H. R. N.; PIETRO, R. C. L. R., O Brasil no contexto de controle de qualidade de plantas medicinais. Revista Brasileira de Farmacognosia, v. 20, n. 3, p. 435-440, jun./ jul. 2010. Disponível em: http://www.scielo.br/pdf/rbfar/v20n3/a23v20n3.pdf. Acesso em:11 dez. 2013.

STRASBURGER, E. Handbook of Practical Botany. New York, The MacMillan Company, 1924.

TROJAN-RODRIGUES, M.; ALVES, T. L. S.; SOARES, G. L. G.; RITTER, M. R. Plants used as antidiabetics in popular medicine in Rio Grande do Sul, southern Brazil. Journal of Ethnopharmacology, v. 139, p. 155-163, 2012. Disponível em: https:/www.sciencedirect.com/science/article/pii/ S0378874111007732/pdfft? md5=f406b426a845c58f29c44192354a72d9\&pid=1-s2.0S0378874111007732-main.pdf. Acesso em: 09 set. 2015.

VAZ, A. M. S. F; TOZZI, A. M. G. A. Sinopse de Bauhinia sect. Pauletia (Cav.) DC. (Leguminosae: Caesalpinioideae: Cercideae) no Brasil. Revista Brasileira de Botânica, v. 28, n. 3, p. 477-491, jul./ set. 2005. Disponível em: http://www.scielo.br/pdf/rbb/v28n3/28999.pdf. Acesso em: 21 ago. 2013.

VENDRUSCOLO, G. S., MENTZ, L. A. Levantamento etnobotânico das plantas utilizadas como medicinais por moradores do Bairro Ponta Grossa, Porto Alegre, Rio Grande do Sul, Brasil. Iheringia, Sér Bot. p. 61, n. 1-2, p. 83-103, 2006. Disponível em: http://www.fzb.rs.gov.br/ upload/20140328134730ih61_p83_103.pdf. Acesso em: 22 nov. 2013.

WHO. The importance of pharmacovigilance: Safety monitoring of medicinal products. United Kingdom, WHO Library Cataloguing-in-Publication Data, 2002. Disponível em: http://apps.who.int/ medicinedocs/pdf/s4893e/s4893e.pdf. Acesso em: 09 abr. 2014.

YOKOTA, A. A; JACOMASSI, J.; LAVERDE JUNIOR, A.; TAKEMURA, O. S. Avaliação da qualidade de produtos contendo Maytenus ilicifolia Mart. ex Reissek - Celastraceae (espinheira-santa) comercializados na cidade de Umuarama-PR. Ciências Biológicas e da Saúde, v. 31, n. 2, p. 159168, jul./dez. 2010. Disponível em: http://www.uel.br/revistas/uel/index.php/seminabio/article/ view/8788/8353. Acesso em: 18 nov. 2015.

Received: August 21, 2017

Accepted: January 12, 2018 